\title{
Evaluation of Pregnancy and Thyroid Function
}

\author{
Chang-Eun Park \\ Department of Biomedical Laboratory Science, Molecular Diagnostics Research Institute, Namseoul University, Cheonan, Korea
}

\section{임신과 갑상선 기능의 평가}

\author{
박창은 \\ 남서울대학교 임상병리학과, 분자진단연구소
}

\begin{abstract}
During early pregnancy, before the development of a functioning thyroid gland, thyroid stimulating hormone (TSH) is a very sensitive marker of thyroid dysfunction during pregnancy. Normal values have been modified during gestation with a downward shift. The fetus is influenced by the TSH supplied by the mother. TSH and free thyroxine (FT4) concentrations vary during pregnancy and conventional units can vary between laboratories. A downward shift of the TSH reference range occurs during pregnancy, with a decrease in both the lower and upper limits of maternal TSH, relative to the typical non-pregnant TSH reference range. Each laboratory produces its own reference TSH and FT4 concentrations because there are many different assays that yield different results in pregnancy. Therefore, automated immunoassays used for serum FT4 analysis are still used widely, but the important considerations discussed above must be noted. The use of population-based, trimester-specific reference ranges remains the best way to handle this issue The slight downward shift in the upper reference range of TSH occurring in the latter first trimester ( $7 \sim 12$ weeks) of pregnancy, typically not observed prior to 7 weeks. Their use indicates high or low levels in a quantitative manner independent of the reference ranges. These data highlight the importance of calculating population-based pregnancy-specific thyroid parameter reference intervals. A precision medicine initiative in this area will require the collection and analysis of a large number of genetic, biological, psychosocial, and environmental variables in large cohorts of individuals. Large prospective randomized controlled trials will be needed to resolve these controversies.
\end{abstract}

Key words: Free T4, Pregnancy, Reference ranges, TSH

This is an Open Access article distributed under the terms of the Creative Commons Attribution Non-Commercial License (http://creativecommons.org/licenses/by-nc/4.0) which permits unrestricted non-commercial use, distribution, and reproduction in any medium, provided the original work is properly cited.

Copyright @ 2018 The Korean Society for Clinical Laboratory Science. All rights reserved.
Corresponding author: Chang-Eun Park Department of Biomedical Laboratory Science, Molecular Diagnostics Research Institute, Namseoul University, 91 Daehak-ro,

Seonghwan-eup, Seobuk-gu, Cheonan 31020 , Korea

Tel: 82-41-580-2722

Fax: 82-41-580-2932

E-mail: eun2777@hanmail.net

Received: January 20, 2018

Revised: February 4, 2018

Accepted: February 4, 2018

\section{INTRODUCTION}

Normal pregnancy is associated with an increase in renal iodine excretion, an increase in thyroxine binding proteins, an increase in thyroid hormone production, and thyroid stimulatory effects of human chorionic gonadotrophin (hCG). There are significant changes in thyroid physiology and function during pregnancy. These are particularly important in the first trimester when the fetus relies on circulating maternal thyroxine (T4). Alteration in the hypothalamic-pituitary-thyroid (HPT) axis and the hypothalamic-pituitary-adrenal (HPA) axis is a main cause of depressive disorder. In the HPT axis make change in thyroid function tests have been reported by various authors [1]. The detection of anti-thyriod peroxidase (TPO-Ab), and anti-thyroglobulin (TG-Ab) antibodies an 
in the context of the clinical presentation of thyroid dysfunction, confirms the diagnosis of thyroid autoimmune disease [2].

The HPT axis and the HPA axis is impaired in geriatric patients with psychiatric disorder. The impairment of both HPA and HPT in our geriatric patients with psychiatric disorder support this good correlation between serum total cholesterol (TC) and TSH. Thyroid function within the euthyroid range was also associated with placental growth, independent from common confounders, such as maternal BMI and serum glucose and lipid concentrations [3]. This dynamic change in thyroid physiology is more relevant in the early stages of gestation and, consequently, TSH reference limits differ widely within the first trimester of pregnancy [4]. Uncorrected thyroid function in pregnancy has adverse effects on fetal and maternal well-being a early pregnancy variation in test result in a woman with a normal hypothalamic-pituitarythyroid gland function (Table 1).

The marked increase in both serum thyroid binding globulin (TBG) concentrations and extrathyroidal T4 distribution space that take place during the first half of gestation. To maintain the homeostasis of $\mathrm{T} 4$ concentrations, the thyroid machinery must produce more $\mathrm{T} 4$ until a new steady state is reached around mid-gestation. TBG increases by $2 \sim 3$ times compared with the pre-pregnancy level by the 20th week of gestation.

Advances in the assessment of thyroid function also have indicated that interpretation of thyroid function tests depend on the stage of pregnancy. Thyroid disorders are prevalent in women of child-bearing age and for this reason commonly present in pregnancy and the puerperium [5].

This review will focus on thyroid function in pregnancy followed by a discussion of thyroid dysfunction and its effects. Thyroid physiology and function in normal pregnancy. Iodine deficiency during pregnancy is associated with maternal goitre and reduced maternal $\mathrm{T} 4$ level, which is seen in areas of endemic cretinism [6].

To date, thyroid function tests are only performed in women at risk for thyroid disorders, whereas we recommend routine screening before and during pregnancy. A recommended daily iodine intake of $250 \mathrm{mg} /$ day (suggested by a WHO consultation) represents an increase from the previous figure of $200 \mathrm{mg} /$ day. In the pregnant woman, a median urinary iodine (UI) of $150 \mathrm{mg} / \mathrm{L}$ is regarded as insufficient, an excretion of $150 \sim 249 \mathrm{mg} / \mathrm{L}$ adequate, that of $250 \sim 499 \mathrm{mg} / \mathrm{L}$ as more than adequate and $500 \mathrm{mg} / \mathrm{L}$ as excessive [7].

During pregnancy, the thyroid gland increases in size by $10 \%$ in iodine replete countries but by $20 \%$ to $40 \%$ in areas of iodine deficiency. For these reasons thyroid function is frequently assessed during the gestation period. However, accurate assessment of maternal (and fetal) thyroid function during pregnancy remains difficult, and interpretation of laboratory testing differs from the non-pregnant patient. The thyroid function tests of healthy pregnant women, therefore, differ from those of healthy non-pregnant women.

Furthermore, the reference ranges for the most widely applied tests, TSH and free thyroxine (FT4), may vary significantly in different populations. A reduction in the lower TSH reference range is observed during pregnancy in almost all studies. Serum concentration of thyroid hormones has been reported to be decreased, increased or unchanged during gestation by different groups depending on the assays used. Assays employing total $\mathrm{T} 4$ show a result approximately 1.5 times the non-pregnant value. There is general consensus that there is a transient rise in FT 4 in the first trimester due to the relatively high circulating hCG

Table 1. Changes in thyroid function that the main mechanisms leading to changes in early pregnancy

\begin{tabular}{lccc}
\hline \multicolumn{1}{c}{ Physiological change } & TSH & Total T4 & Free T4 \\
\hline hCG secretion & High decrease $(\downarrow \downarrow \downarrow)$ & Low increase $(\uparrow)$ & Low increase $(\uparrow)$ \\
Estrogen induced TBG increase & Low increase $(\uparrow)$ & Middle increase $(\uparrow \uparrow)$ & Low decrease $(\downarrow)$ \\
Effected intact thyroid & Middle decrease $(\downarrow \downarrow)$ & Middle increase $(\uparrow \uparrow)$ & Low increase $(\uparrow)$ \\
\hline
\end{tabular}

Abbreviations: TSH, thyroid stimulating hormone; T4, thyroxine; hCG, human chorionic gonadotrophin; TBG, thyroid binding globulin. 
concentration and a decrease of FT4 in the second and third trimester albeit within the normal reference range [8].

The thyroid hormone and high molecular weight (HMW)adiponectin may be linked together in the regulation of energy metabolism in human pregnancy. also, the thyroid hormones and markers of glucose tolerance and insulin resistance thyroid hormones regulate hepatic gluconeogenesis and modulate mRNA and protein expression of glucose transporters. TSH decreases transiently during the first trimester of pregnancy and increases thereafter (without attaining pregravid levels), with similar but inverse changes in serum FT4 and free T3 (FT3). The FT3 is associated with smoking, even after accounting for the effect of obesity, body fat distribution, insulin, and metabolic parameters [9].

Ideally, the assay specific TSH reference ranges for each trimester should be calculated based on the local population in iodine sufficient areas and pregnant women recruited for such calculations should be euthyroid and thyroid antibody negative. The reviewed in the guidelines of several societies including the American Thyroid Association (ATA) and the Endocrine Society and the European Thyroid Association (ETA) during pregnancy (Table 2).

However, important uncertainties remain regarding both the screening and management of maternal thyroid status in optimizing perinatal outcomes [13].

Therefore, this review provide of thyroid function reference intervals during pregnancy and different factors that contribute to these intervals, as well as the clinical complications associated with minor variations in thyroid function. While universal screening versus case finding for thyroid dysfunction increased diagnosis and subsequent management, it did not lead to clear differences in the primary outcomes.

\section{MAIN ISSUE}

The largest decrease in serum TSH is observed during the first trimester because of elevated levels of serum hCG directly stimulating the TSH receptor and thereby increasing thyroid hormone production. hCG levels increase following fertilization and peak at 10 12 weeks of gestation, leading to a rise in the total serum T4 and T3 concentrations and subsequently reduction of thyrotropin-releasing hormone (TRH) and TSH levels as a result of negative feedback. TSH is the most sensitive indicator of thyroid function. Interpretation of free $\mathrm{T} 4$ and $\mathrm{T} 3$ levels during pregnancy is difficult, as higher TBG and lower albumin levels decrease accuracy of immunoassays, causing falsely low levels in the third trimester [14].

Furthermore, up to $18 \%$ of all pregnant women are TPOAb or TgAb positive. Increasingly, data suggest that TPOAb positivity adversely modulates the impact of maternal thyroid status (especially hypothyroidism) on the pregnancy and the developing fetus. Thyroid antibody positivity separately increases the risk of thyroid dysfunction following delivery and during the postpartum period. The circulating TBG and total T4 (TT4) concentrations increase by week 7 of gestation and reach a peak by approximately week 16 of gestation and then high until delivery [15].

Table 2. TSH reference ranges in pregnancy

\begin{tabular}{|c|c|c|c|c|}
\hline \multirow[b]{2}{*}{$\begin{array}{l}\text { Screening at any moment } \\
\text { during pregnancy }\end{array}$} & \multicolumn{3}{|c|}{ TSH reference ranges (mIU/L) and upper limit } & \multirow[b]{2}{*}{ References } \\
\hline & $\begin{array}{l}\text { American Endocrine } \\
\text { Society }\end{array}$ & $\begin{array}{c}\text { American Thyroid Association } \\
\text { and European Thyroid } \\
\text { Association }\end{array}$ & $\begin{array}{l}\text { Observation } \\
\text { Study }\end{array}$ & \\
\hline First trimester & $0.1 \sim 2.5$ & $<2.5$ & 3.47 & {$[10-12]$} \\
\hline Second trimester & $0.2 \sim 3.0$ & $<3.0$ & 3.81 & \\
\hline Third trimester & $0.3 \sim 3.0$ & $<3.5$ & 4.99 & \\
\hline Before 20 weeks of gestation & & & 4.08 & \\
\hline Before 14 weeks of gestation & & & 2.5 & \\
\hline Before 15 weeks of gestation & & & 2.53 & \\
\hline
\end{tabular}


Serum hCG concentrations tend to be higher and TSH concentrations lower in women with multiple pregnancies, and that women with multiple pregnancies should be excluded from reference populations to determine TSH reference intervals. In the first trimester, maternal hCG directly stimulates the TSH receptor, increasing thyroid hormone production and resulting in a subsequent reduction in serum TSH concentration [16]. Therefore, during pregnancy, women have lower serum TSH concentrations than before pregnancy, and a TSH below the non-pregnant lower limit of $0.4 \mathrm{mIU} / \mathrm{L}$ is observed in as many as $15 \%$ of healthy women during the first trimester of pregnancy [17].

The serum TSH and its reference range gradually rise in the second and third trimesters, but nonetheless remain lower than in non-pregnant women [18]. Since hCG concentrations are higher in multiple pregnancies than in singleton pregnancies, the downward shift in the TSH reference interval is greater in twin pregnancies [19]. The fraction of women with a suppressed TSH falls to about $10 \%$ in the second trimester, and 5\% in the third trimester [20].

The normal thyroid function before pregnancy and at the first trimester of pregnancy in women with normal somatotroph function, Persechini et al (2015) observed a significant decrease of insulin-like growth factor 1 (IGF-1) levels during the first trimester of pregnancy without significant changes in growth hormone (GH) or insulin-like growth factor binding protein 3 (IGF-BP3) concentrations, suggesting liver resistance to the effect of GH secondary to the physiological secretion of estrogens [21]. Women can be classified in normal or pathological TSH values only depending on their gestational age at the time of thyroid test in first trimester [22].

There are two forms of the iodothyronine deiodinase expressed by human placenta: the type 2 (D2) and the type 3 (D3), and their levels decline with pregnancy progression [23]. The D3 is believed to play a role in protecting the developing fetus from excessive maternal transfer of thyroid hormones. However, a TSH cut-off of $2.5 \mathrm{mIU} / \mathrm{L}$ or $4.5 \mathrm{mIU} / \mathrm{L}$ in women who underwent in vitro fertilization
(IVF) [24]. or intrauterine insemination [25]. and it was not show differences in the rates of clinical pregnancy, delivery or miscarriage. These results are in consonance with the hypothesis that the risk of adverse pregnancy outcomes is lower in women with a relatively normal response to hCG [26]. as must occur in successful cycles in assisted reproduction.

Automated immunoassays for FT4, which are employed in most clinical laboratories, are complicated in pregnant women by the increase in TBG and decrease in albumin concentrations. Other methods of direct measurement, such as measurement by equilibrium dialysis (ED), ultrafiltration, or liquid chromatography/tandem mass spectrometry (LC/MS/MS) are less influenced by the pregnancy associated changes in serum proteins but are significantly more expensive and less widely available.

The international federation of clinical chemistry (IFCC) working group proposed FT4 measurement by ED combined with isotope dilution-liquid chromatography/ tandem mass spectrometry (ED ID-LC/tandem MS) as the reference measurement procedure (RMP) to measure serum FT4 [27].

It is recommended that each laboratory produces its own reference TSH and FT4 concentrations as there are many different thyroid hormone assays which yield different results in pregnancy [28]. Reference ranges are widely used but they do not indicate how a particular concentration is likely to be associated with clinical disease [29].

Free T4 reference limits may be slightly higher ( 5\%) than non-pregnancy reference limits in pregnancy weeks 9 12. Correct free T4 (and free T3) analytical results are obtained with methods that include an initial isolation of the free hormone by ultrafiltration or dialysis followed by direct measurement of hormone in filtrate/dialysate by mass spectrometry (or sensitive radioimmunoassay) [30].

TSH can be undetectable ( $<0.01 \mathrm{mIU} / \mathrm{L})$, and yet still represent a normal pregnancy, a maternal TSH concentration that is low but detectable is likely not clinically significant [31]. The TSH, TT4, total triiodothyronine (TT3), FT4 and FT3 ranges have been shown to vary 
slightly depending on different methods of analysis, although this variation is not clinically significant [32-34].

The maternal high-normal FT4 concentrations in early pregnancy are associated with lower birth weight and an increased risk of small for gestational age newborns and in pregnant women without a history of thyroid dysfunction. Serum TSH reference range determinations should take into account iodine intake, TPO (thyroid peroxidase) positivity, and according to some studies, body mass index (BMI). and the maternal thyroid measurements are related to both prepregnancy BMI and weight gain throughout gestation [35]. Initial studies of pregnant women in the United States and Europe first led to recommendations for a TSH upper reference limit of $2.5 \mathrm{mIU} / \mathrm{L}$ in the first trimester and $3.0 \mathrm{mIU} / \mathrm{L}$ in the second and third trimesters [36]. During pregnancy, the Korean have demonstrated only a modest reduction in the upper reference limit [37].

In study, pregnant women show a modest reduction in the first-trimester upper TSH limit of 0.5 1.0 mIU/L. In some cases, this was not statistically different from the non-pregnant state. One approach to reducing this variability is to use the Multiple of Medians calculation to compare values between assays This calculation divides an individual value by the population median The resulting value is not influenced by the differences between assays [38].

The merit in converting TSH and FT4 values to laboratory gestation-specific multiples of the median (MoMs), and also some advantage in taking account of other factors that influence these concentrations. It is important to specify laboratory and gestation specific medians. Adjusting for other factors reduces variance of the distributions, but only to a small extent. Ethnic status has been shown to influence the two hormone levels but this was not collected as part of the CATS (controlled antenatal thyroid screening) study. It has been shown that ethnic status could be included if such data were available; previous work has shown that both hormones are, on average, statistically significantly lower in blacks than whites [39].

MoM values also allow for the factors that influence TSH and FT4 values, such as gestational age and maternal weight. Anti-TPO or anti-Tg thyroid autoantibodies are present in $2 \%$ to $17 \%$ of unselected pregnant women [40-43].

Dietary iodine intake may also be associated with anti-thyroid Ab positivity during pregnancy Those women with isolated TgAb positivity had a significantly higher serum TSH than women without thyroid autoimmunity. The prevalence of antithyroid antibodies may be higher in women with polycystic ovarian syndrome (PCOS) than in age-matched controls [44]. Antithyroid antibodies are detectable in the ovarian follicles of women with thyroid autoimmunity and correlate with serum antibody levels [45]. Although whether such antibodies interfere with the fertilization potential of maturing oocytes is unknown.

Elevations in serum TSH concentrations during pregnancy should ideally be defined using pregnancy- and population specific reference ranges. It is important to note that detection of an increased TSH concentration is not always synonymous with decreased FT4 concentrations. Frequently, elevated maternal TSH is detected when FT4 concentrations are normal. Serum FT4 concentrations increase and TSH concentrations decrease from approximately the eighth week throughout the first half of pregnancy, resulting in different reference intervals for TSH and FT 4 compared to the non-pregnant state.

Except for measurement of maternal thyroid function, should additional maternal or fetal testing occur in treated hypothyroid women during pregnancy. In the care of women with adequately treated hypothyroidism, no other maternal or fetal testing (such as serial fetal ultrasounds, antenatal testing, and/or umbilical blood sampling) is recommended beyond measurement of maternal thyroid function unless needed due to other circumstances of pregnancy. An exception to this is women with GD (Graves' disease) effectively treated with ${ }^{131}$ I ablation or surgical resection, who require TSH receptor antibody (TRAb) monitoring.

The measurement of serum TSH concentration should be performed as soon as pregnancy is confirmed, with reflex anti-TPOAb if TSH is $2.5 \sim 10 \mathrm{mU} / \mathrm{L}$ (Figure 1). 


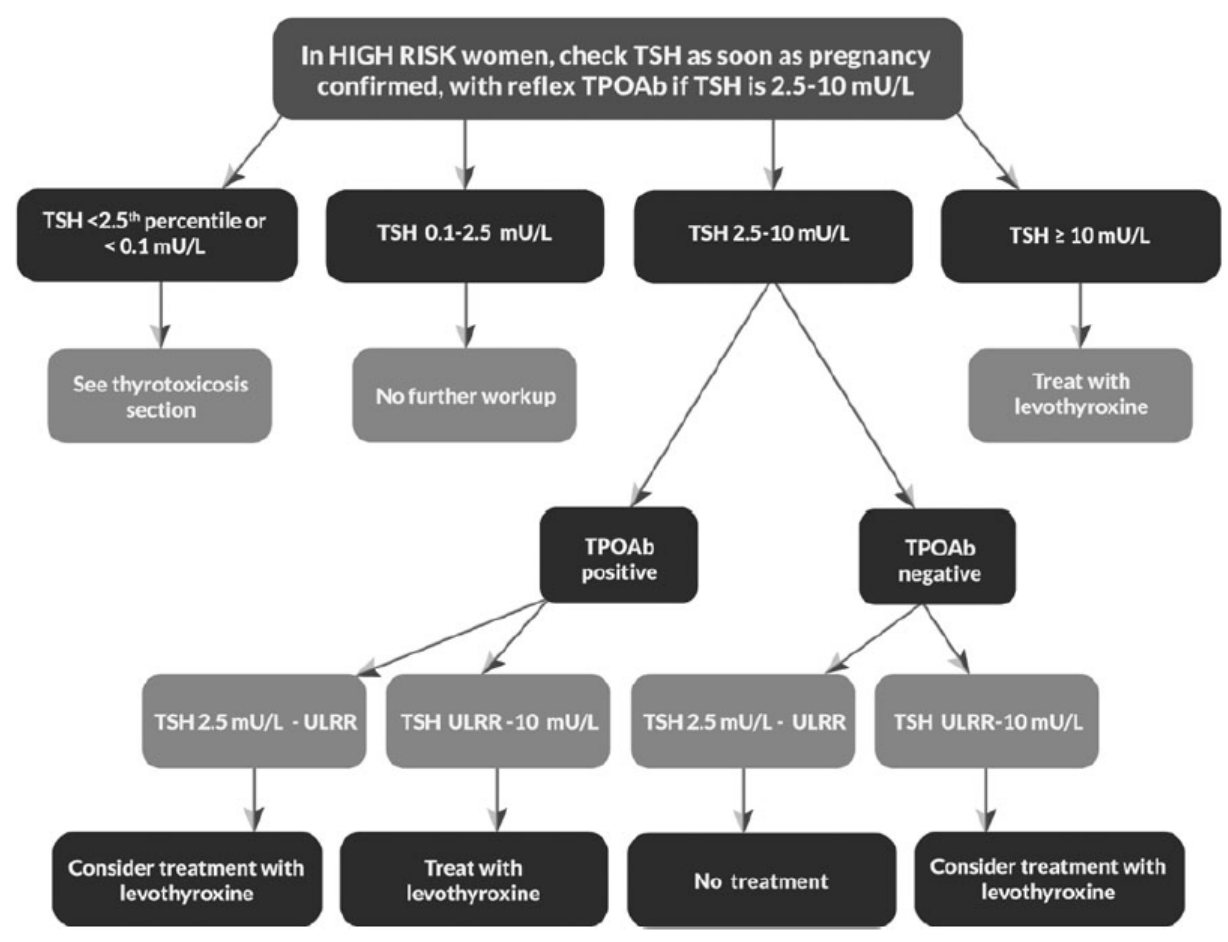

Figure 1. Testing for thyroid dysfunction in pregnancy. ULRR, upper limit of the reference range. Source: Reference [46], Alexander EK, et al. 2017 Guidelines of the American thyroid association for the diagnosis and management of thyroid disease during pregnancy and the postpartum. Thyroid. 2017;27(3):315389.

Medici et al. [47] were recommended that institutions should not rely on a fixed universal cutoff concentration worldwide, but should calculate their own pregnancyspecific population-based reference intervals. If such reference intervals are not available, adopting populationbased reference intervals from a population with similar characteristics is the best option.

Recently, prenatal diagnosis a role in the management of pregnant women with resistance to thyroid hormone (RTH- $\beta$ ). It's a fetal-maternal interaction occurring during pregnancy in a woman with RTH- $\beta$, it may be safe to delay prenatal diagnosis until the maternal FT4 surpasses 50\% above the upper limit of normal (ULN) for gestational age. This recommendation is based on the normal birth weight and non-suppressed TSH [48].

TSH is lowest in the afternoon, rises in the evening with a peak in the early half of the night [49]. Circadian variation was also shown to be maintained in the second and third trimesters [50]. The time of collection has the potential to introduce unhelpful noise into the interpretation of patient results.

\section{CONCLUSION}

Women have lower TSH levels in pregnancy than in the non-pregnant state and international bodies now recommend that trimester-specific reference ranges be used in pregnancy. Thyroid dysfunction is the commonest endocrine disorder in pregnancy apart from diabetes. Approximately $94 \%$ of thyroid hormones are secreted by the thyroid gland as thyroxine or T4 and 6\% as T3. Early diagnosis and management of thyroid dysfunction in pregnancy is essential to avoid adverse maternal and fetal outcomes. Robinson et al were a significant proportion of women with known thyroid disease either have inadequately (according to current guidelines) treated thyroid disease or untested thyroid function in the first trimester [51].

These differences can be explained by variations in assays as well as population-specific factors, such as ethnicity and body mass index. Autoimmune thyroid diseases tend to improve during pregnancy but commonly flare-up or emerge in the post-partum period. Accordingly, thyroid auto-antibodies tend to decrease with pregnancy progression [52]. Maternal thyroid dysfunction, especially hypothyroidism and thyroid autoimmunity, negatively 
affects fetal development and leads to first trimester miscarriages as well as gestational disorders [53].

In pregnant women without a history of thyroid dysfunction, lower concentrations of FT4 and a higher conversion of FT4 to FT3, as inferred by changes in the FT3-to-FT4 ratio, are associated with a less favorable metabolic phenotype and with placental growth [54]. Maternal volume expansion in the second trimester of pregnancy may be a confounding factor in association studies of soluble biomarkers [55].

The assay specific TSH reference ranges is not feasible, a reasonable alternative is to use the consensus ranges as per the various guidelines. Data were lacking on some health outcomes, including many important short- and long-term infant and child outcomes, and on impacts on use of health services and costs [36,56].

McNeil and Stanford were reported to thyroid function test reference intervals in pregnancy for the five instrument groups that are commonly used in Australia and New Zealand [57]. Its a first trimester TSH 97.5th percentiles fell into two groups-Architect, Beckman and Immulite were around $3.0 \mathrm{mIU} / \mathrm{L}$ whilst Centaur and Roche were closer to $4.0 \mathrm{mIU} / \mathrm{L}$. FT4 seemed more consistent across methods with an interval of approximately $11.5 \sim 19 \mathrm{pmol} / \mathrm{L}$ in the first trimester and slightly lower values later in pregnancy. The exception was the Beckman Access groups where the concentrations were considerably lower.

The management of thyroid disease during pregnancy has been reviewed in the guidelines of several societies including the American Thyroid Association (ATA) and the Endocrine Society and the European Thyroid Association (ETA). If these reference ranges are not available in the laboratory, the following reference ranges can be used: first trimester, 0.1 to $2.5 \mathrm{mIU} / \mathrm{L}$; second trimester, 0.2 to $3.0 \mathrm{mIU} / \mathrm{L}$; third trimester, 0.3 to $3.0 \mathrm{mIU} / \mathrm{L}$. Serum TSH concentration may also be affected by many other factors including analytical method, thyroid autoantibody status, ethnicity, and iodine nutrition. Appropriate management of thyroid disease during pregnancy is important for maternal and fetal health. Further research is needed to address many questions, including the utility of universal screening of pregnant women for thyroid dysfunction and thyroid autoimmunity, and the efficacy of treatment of subclinical hypothyroidism [58].

Clinical evaluation of the patient's symptoms as well as laboratory testing should be done carefully to assess thyroid function during pregnancy. It is recommended that all pregnant mothers should be given thyroid function test and those who have thyroid dysfunction should be provided appropriate treatment and follow up until there will have normal thyroid function. Despite the lack of consensus among professional organizations, recent studies which have been performed on the basis of sophisticated analyses have found that screening all pregnant women [59].

There are significant advantages in using laboratory and gestational age specific TSH and FT4 MoM values in pregnancy instead of using arbitrary reference ranges

If trimester specific reference ranges are not available in the laboratory, then international bodies recommend a TSH level. Due to the changes in thyroid physiology, some pregnant women taking thyroxine need increased doses of thyroxine from as early as the fifth week of gestation. For women taking thyroxine prior to pregnancy who had a TSH tested at the time of referral to antenatal services, $51 \%$ had a TSH level outside of pregnancy reference ranges [60].

The results of this review show that universal screening for thyroid dysfunction is effective in identifying more women who can subsequently be treated. One of the included trials in this review is currently undertaking further follow-up of development stage although statistical evidence to justify universal screening is lacking, more evidence will be produced in the future in favor of routine testing.

In this paper, a focusing on these controversial issues to produce critically needed data on the impact of treating these subclinical forms of thyroid disease and during pregnancy. 


\section{요 약}

갑상선의 기능적 발달 이전인 임신초기에 갑상선자극호르몬 은 갑상선 장애 및 임신 동안 매우 민감한 지표이다. 임신동안 정 상수준은 감소 변화를 보이는 것은 모체로부터 태아가 받는 갑 상선호르몬의 영향이다. 갑상선자극호르몬과 유리 티록신의 농도는 임신동안 및 검사실간에 다양하게 보고된다. 갑상선자 극호르몬의 참고치는 비임신군에 비하면 상한값과 하한값의 참 고범위의 감소가 임신동안 보인다. 각 실험실은 임신 중에 다른 결과를 산출하는 호르몬 분석법과 일부 자체 기준에 맞는 혈중 농도를 산출한다. 따라서, 혈청 유리 티록신 분석에 사용되는자 동화 된 면역 분석법은 여전히 널리 사용되고 있지만 고려할 사 항이 있다. 집단 기준, 삼분위 기간별 특이적 참고범위 사용은 문제해결의 최상의 방법이다. 임신 7 12주에 발생하는 호르몬 의 하향은 7 주 이전에는 보이지 않아 참고범위의 개별적 정량적 으로 상승 및 하강을 보여준다. 본 연구에서는 집단별과 임신 특 이적 갑상선 매개 변수의 참조범위에 대한 산출 중요성을 강조 한다. 정밀의학 의 도래에 있어서 많은 개체의 유전적, 생물학 적, 심리사회학적, 환경적 변수를 수집하고 분석이 필요하다. 이 러한 논쟁을 해결하기 위해서는 다량의 전향적인 무작위 통제 연구가 필요하다.

Acknowledgements: Funding for this paper was provided by Namseoul University year 2017.

Funding: None

Conflict of interest: None

\section{REFERENCES}

1. Jackson I. The thyroid axis and depression. Thyroid. 1998; 8(10):951-956.

2. Pop V, Maartens L, Leusink G, van Son M, Knottnerus A, Ward A, et al. Are autoimmune thyroid dysfunction and depression related? J Clin Endocrinol Metab. 1998;83(9):3194-3197.

3. Herrera E, Ortega-Senovilla H. Disturbances in lipid metabolism in diabetic pregnancy-are these the cause of the problem? Best Pract Res Clin Endocrinol Metab. 2010;24(4):515525.

4. Laurberg P, Andersen SL, Hindersson P, Nohr EA, Olsen J. Dynamics and predictors of serum TSH and fT 4 reference limits in early pregnancy: a study within the Danish National Birth Cohort. J Clin Endocrinol Metab. 2016;101(6):2484-2492.

5. Krassas GE, Poppe K, Glinoer D. Thyroid function and human reproductive health. Endocr Rev. 2010;31(5):702-705.

6. Lazarus JH, Smyth PPA. Iodine deficiency in pregnancy: iodine deficiency and supplementation in pregnancy. In: Preedy
Victor R., Burrow Gerard N., Watson Ronald, (eds). Comprhensive Handbook of Iodine: Nutritional, Biochemical, Pathological and Therapeutic Aspects. Oxford: Academic, 2009,469-476

7. Andersson M, De Benoist B, Delange F, Zupan J. Prevention and control of iodine deficiency in pregnant and lactating women and in children less than 2- years-old: conclusions and recommendations of the Technical Consultation. Public Health Nutr. 2007;10(12A):1606-1611.

8. Brent GA. Maternal thyroid function: interpretation of thyroid function tests in pregnancy. Clin Obstet Gynecol. 1997;40(1): 3-15.

9. Shields B, Hill A, Bilous M, Knight B, Hattersley AT, Bilous RW, et al. Cigarette smoking during pregnancy is associated with alterations in maternal and fetal thyroid function. J Clin Endocrinol Metab. 2009;94(2):570-574.

10. Garber JR, Cobin RH, Gharib H, Hennessey JV, Klein I, Mechanick JI, et al. Clinical practice guidelines for hypothyroidism in adults: cosponsored by the American Association of Clinical Endocrinologists and the American Thyroid Association. Endocr Pract. 2012;18(6):988-1028.

11. Tingi E, Syed AA, Kyriacou A, Mastorakos G, Kyriacou A. Benign thyroid disease in pregnancy: A state of the art review. J Clin Transl Endocrinol. 2016;23(6):37-49.

12. Velasco I, Taylor P. Identifying and treating subclinical thyroid dysfunction in pregnancy: emerging controversies. Eur J Endocrinol. 2018;178(1):D1-D12. doi: 10.1530/EJE-17-0598.

13. Stagnaro-Green A. Clinical guidelines: thyroid and pregnancytime for universal screening? Nat Rev Endocrinol. 2017;13(4): 192-194. doi: 10.1038/nrendo.2017.17.

14. Lee RH, Spencer CA, Mestman JH, Miller EA, Petrovic I, Braverman LE, et al. Free T4 immunoassays are flawed during pregnancy. Am J Obstet Gynecol. 2009; 200(3):260.e1-260.e6.

15. Weeke J, Dybkjaer L, Granlie K, Eskjaer Jensen S, Kjaerulff E, Laurberg P, et al. A longitudinal study of serum TSH, and total and free iodothyronines during normal pregnancy. Acta Endocrinologica. 1982;101(4):531-537.

16. Baloch Z, Carayon P, Conte-Devolx B, Demers LM, Feldt-Rasmussen U, Henry JF, et al. Laboratory medicine practice guidelines. Laboratory support for the diagnosis and monitoring of thyroid disease. Thyroid. 2003;13(1):3-126.

17. Orito Y, Oku H, Kubota S, Amino N, Shimogaki K, Hata M, et al. Thyroid function in early pregnancy in Japanese healthy women: relation to urinary iodine excretion, emesis, and fetal and child development. J Clin Endocrinol Metab. 2009;94(5):16831688.

18. Haddow JE, Knight GJ, Palomaki GE, McClain MR, Pulkkinen AJ. The reference range and within-person variability of thyroid stimulating hormone during the first and second trimesters of pregnancy. J Med Screen. 2004;11(4):170-174.

19. Sapin R, D’Herbomez M, Schlienger JL. Free thyroxine measured with equilibrium dialysis and nine immunoassays decreases in late pregnancy. Clin Lab. 2004;50(9-10):581-584.

20. Glinoer D. The regulation of thyroid function in pregnancy: pathways of endocrine adaptation from physiology to pathology. Endocr Rev. 1997;18(3):404-433.

21. Persechini ML, Gennero I, Grunenwald S, Vezzosi D, Bennet A, Caron P. Decreased IGF-1 concentration during the first tri- 
mester of pregnancy in women with normal somatotroph function. Pituitary. 2015;18(4):461-464.

22. Murillo-Llorente M, Fajardo-Montañana C, Pérez-Bermejo M, Vila-Candel R, Gómez-Vela J, Velasco I. Intra-individual variability in TSH levels of healthy women during the first half of pregnancy. Endocrinol Diabetes Nutr. 2017;64(6):288-294.

23. Chan SY, Vasilopoulou E, Kilby MD. The role of the placenta in thyroid hormone delivery to the fetus. Nat Clin Pract Endocrinol Metab. 2009;5(1):45-54.

24. Reh A, Grifo J, Danoff A. What is a normal thyroid-stimulating hormone (TSH) level? Effects of stricter TSH thresholds on pregnancy outcomes after in vitro fertilization. Fertil Steril. 2010;94(7):2920-2922.

25. Karmon AE, Batsis M, Chavarro JE, Souter I. Preconceptional thyroid-stimulating hormone levels and outcomes of intrauterine insemination among euthyroid infertile women. Fertil Steril. 2015;103(1):258-263.

26. Korevaar TI, Steegers EA, Pop VJ, Broeren MA, Chaker L, de Rijke YB, et al. Thyroid autoimmunity impairs the thyroidal response to human chorionic gonadotropin: two populationbased prospective cohort studies. J Clin Endocrinol Metab. 2017;102(1):69-77.

27. Thienpont LM, Beastall G, Christofides ND, Faix JD, Ieiri T, Miller WG, et al. Proposal of a candidate international conventional reference measurement procedure for free thyroxine in serum. Clin Chem Lab Med. 2007;45(7):934-936.

28. d'Herbomez M, Forzy G, Gasser F, Massart C, Beaudonnet A, Sapin R. Clinical evaluation of nine free thyroxine assays: persistent problems in particular populations. Clin Chem Lab Med. 2003;41(7):942-947.

29. Wald NJ. The triple test. Clin Chem, 2014;60(1):269-270.

30. Laurberg P, Andersen SL. Endocrinology in pregnancy: Pregnancy and the incidence, diagnosing and therapy of Graves' disease. Eur J Endocrinol. 2016 ;175(5):R219-30.

31. Casey BM, Dashe JS, Wells CE, McIntire DD, Leveno KJ, Cunningham FG. Subclinical hyperthyroidism and pregnancy outcomes. Obstet Gynecol. 2006;107(2 Pt 1):337-341.

32. Thienpont LM, Van Uytfanghe K, Beastall G, Faix JD, Ieiri T, Miller WG, et al. Report of the IFCC working group for standardization of thyroid function tests; part 1: thyroid-stimulating hormone. Clin Chem. 2010;56(6):902-911.

33. Thienpont LM, Van Uytfanghe K, Beastall G, Faix JD, Ieiri T, Miller WG, et al. Report of the IFCC working group for standardization of thyroid function tests; part 2: free thyroxine and free triiodothyronine. Clin Chem. 2010;56(6):912-920.

34. Thienpont LM, Van Uytfanghe K, Beastall G, Faix JD, Ieiri T, Miller WG, et al. Report of the IFCC working group for standardization of thyroid function tests; part 3: total thyroxine and total triiodothyronine. Clin Chem. 2010;56(6):921-929.

35. Pop VJ, Biondi B, Wijnen HA, Kuppens SM, Lvader H. Maternal thyroid parameters, body mass index and subsequent weight gain during pregnancy in healthy euthyroid women. Clin Endocrinol (Oxf). 2013;79(4):577-583.

36. De Groot L, Abalovich M, Alexander EK, Amino N, Barbour L, Cobin RH, et al. Management of thyroid dysfunction during pregnancy and postpartum: an endocrine society clinical practice guideline. J Clin Endocrinol Metab. 2012;97(8):2543-2565.
37. Moon HW, Chung HJ, Park CM, Hur M, Yun YM. Establishment of trimester-specific reference intervals for thyroid hormones in Korean pregnant women. Ann Lab Med. 2015;35(2):198-204.

38. Bestwick JP, John R, Maina A, Guaraldo V, Joomun M, Wald NJ, et al. Thyroid stimulating hormone and free thyroxine in pregnancy: expressing concentrations as multiples of the median (MoMs). Clin Chim Acta. 2014;430:33-37. doi: 10.1016/j.cca. 2013.12.030.

39. Ashoor G, Kametas NA, Akolekar R, Guisado J, Nicolaides KH. Maternal thyroid function at 11-13 weeks of gestation. Fetal Diagn Ther. 2010;27(3):156-163.

40. Moreno-Reyes R, Glinoer D, Van Oyen H, Vandevijvere S. High prevalence of thyroid disorders in pregnant women in a mildly iodine-deficient country: a population based study. J Clin Endocrinol Metab. 2013;98(9):3694-3701.

41. Ashoor G, Maiz N, Rotas M, Jawdat F, Nicolaides KH. Maternal thyroid function at 11 to 13 weeks of gestation and subsequent fetal death. Thyroid. 2010;20(9):989-993.

42. Benhadi N, Wiersinga WM, Reitsma JB, Vrijkotte TG, Van der Wal MF, Bonsel GJ. Ethnic differences in TSH but not in free T4 concentrations or TPO antibodies during pregnancy. Clin Endocrinol (Oxf). 2007;66(6):765-770.

43. La'ulu SL, Roberts WL Second-trimester reference intervals for thyroid tests: the role of ethnicity. Clin Chem. 2007;53(9): 1658-1664.

44. Kachuei M, Jafari F, Kachuei A, Keshteli AH. Prevalence of autoimmune thyroiditis in patients with polycystic ovary syndrome. Arch Gynecol Obstet. 2012;285(3):853-856.

45. Monteleone P, Parrini D, Faviana P, Carletti E, Casarosa E, Uccelli A, et al. Female infertility related to thyroid autoimmunity: the ovarian follicle hypothesis. Am J Reprod Immunol. 2011;66(2):108-114.

46. Alexander EK, Pearce EN, Brent GA, Brown RS, Chen H, Dosiou C, et al. 2017 Guidelines of the American thyroid association for the diagnosis and management of thyroid disease during pregnancy and the postpartum. Thyroid. 2017;27(3):315-389.

47. Medici M, Korevaar TI, Visser WE, Visser TJ, Peeters RP. Thyroid function in pregnancy: what is normal? Clin Chem. 2015;61(5): 704-713.

48. Pappa T, Anselmo J, Mamanasiri S, Dumitrescu AM, Weiss RE, Refetoff S. Prenatal diagnosis of resistance to thyroid hormone and its clinical implications. J Clin Endocrinol Metab. 2017; 102(10):3775-3782.

49. Roelfsema F, Veldhuis JD. Thyrotropin secretion patterns in health and disease. Endocr Rev. 2013;34(5):619-657.

50. Roti E, Bartalena L, Minelli R, Salvi M, Gardini E, Pistolesi A, et al. Circadian thyrotropin variations are preserved in normal pregnant women. Eur J Endocrinol. 1995;133(1):71-74.

51. Robinson H, Robinson P, D'Emden M, Mahomed K. Management of thyroid disease in pregnancy-Room for improvement in the first trimester. Obstet Med. 2016;9(3):126-129.

52. Tingi E, Syed AA, Kyriacou A, Mastorakos G, Kyriacou A. Benign thyroid disease in pregnancy: A state of the art review. J Clin Transl Endocrinol. 2016;6:37-49. doi: 10.1016/j.jcte.2016.11.001.

53. Budenhofer BK, Ditsch N, Jeschke U, Gärtner R, Toth B. Thyroid (dys-)function in normal and disturbed pregnancy. Arch Gynecol Obstet. 2013;287(1):1-7. 
54. Bassols J, Prats-Puig A, Soriano-Rodríguez P, García-González MM, Reid J, Martínez-Pascual M, et al. Lower free thyroxin associates with a less favorable metabolic phenotype in healthy pregnant women. J Clin Endocrinol Metab. 2011;96(12):37173723.

55. Faupel-Badger JM, Hsieh CC, Troisi R, Lagiou P, Potischman N. Plasma volume expansion in pregnancy: implications for biomarkers in population studies. Cancer Epidemiol Biomarkers Prev. 2007;16(9):1720-1723.

56. Lazarus J, Brown RS, Daumerie C, Hubalewska-Dydejczyk A, Negro R, Vaidya B. European thyroid association guidelines for the management of subclinical hypothyroidism in pregnancy and in children. Eur Thyroid J. 2014;3(2):76-94.

57. McNeil AR, Stanford PE. Reporting thyroid function tests in pregnancy. Clin Biochem Rev. 2015;36(4):109-126.

58. Yalamanchi S, Cooper DS. Thyroid disorders in pregnancy. Curr Opin Obstet Gynecol. 2015;27(6):406-415.

59. Krassas G, Karras SN, Pontikides N. Thyroid diseases during pregnancy: a number of important issues. Hormones (Athens). 2015;14(1):59-69.

60. Abalovich M, Gutierrez S, Alcaraz G, Maccallini G, Garcia A, Levalle O. Overt and subclinical hypothyroidism complicating pregnancy. Thyroid. 2002;12(1):63-68. 